\title{
Actinic Keratosis and Cutaneous Squamous Cell Carcinoma
}

\author{
Treatment Options \\ Ralf Gutzmer, Susanne Wiegand, Oliver Kölbl, Kai Wermker, Markus Hepp, and Carola Berking
}

Skin Cancer Center Hannover, Department of Dermatology, Hannover Medical School: Prof. Dr. med. Ralf Gutzmer

Department of Otorhinolaryngology, Head and Neck Surgery, University Hospital Leipzig:

Prof. Dr. med. Susanne Wiegand

Department of Radiotherapy, University Hospital Regensburg: Prof. Dr. med. Oliver Kölbl

Department of Oromaxillofacial, Plastic and Esthetic Surgery, Osnabrück Hospital $\mathrm{GmbH}$, Osnabrück: PD Dr. med. Dr. med. dent. Kai Wermker

Department of Dermatology and Allergology, University Hospital (LMU), Munich: Dr. med. Markus Heppt, Prof. Dr. med. Carola Berking

\section{Summary \\ Background: Cutaneous squamous cell carcinoma (cSCC) and its precursors, actinic keratoses (AK), are common. Physicians of multiple specialties are confronted with their treatment.}

Methods: This review is based on publications retrieved by a selective search in PubMed, as well as on the German guidelines on AK and CSCC, skin cancer prevention, and surgery with histologic guidance.

Results: Local treatments for AK include lesional cryotherapy, curettage, and laser ablation as well as field-directed treatments with topical agents, e.g., diclofenac plus hyaluronic acid, imiquimod, 5-fluorouracil, ingenol mebutate, and photodynamic therapy. These treatments can be administered in various sequences or combinations, depending on individual factors and the stage of the disease. The gold standard of treatment for CSCC is histologically confirmed complete resection; radiotherapy is an alternative. Locally uncontrollable or metastatic disease is treated with systemic drugs. The use of various chemotherapeutic agents, EGFR-directed therapies, and the PD-I inhibitor cemiplimab, either singly or in combination, has been described in uncontrolled trials and case series. Cemiplimab has a reported response rate of $47 \%$ and was recently approved for the treatment of advanced cSCC.

Conclusion: There are many options for the treatment of AK and CSCC that must be considered in the interdisciplinary care of these entities.

\section{Cite this as:}

Gutzmer R, Wiegand S, Kölbl O, Wermker K, Heppt M, Berking C: Actinic keratosis and cutaneous squamous cell carcinomatreatment options. Dtsch Arztebl Int 2019; 116: 616-26; DOI: 10.3238/arztebl.2019.0616

A ctinic keratosis (AK) consists of the intradermal proliferation of histologically atypical keratinocytes in an area of skin that has been chronically damaged by exposure to ultraviolet light (UV). AK presents as reddish or brownish spots or plaques with increased keratosis on areas of the skin that have been exposed to the sun. If the entire thickness of the skin contains atypical keratinocytes, but the basal membrane is preserved, this is called carcinoma in situ, or Bowen's disease (1). Multiple lesions in a contiguous area of skin with visible UV-induced skin damage (e.g., on the scalp, forehead, or dorsa of the hand) are called field

The definition of actinic keratosis

Actinic keratosis (AK) consists of the intradermal proliferation of histologically atypical keratinocytes in an area of skin that has been chronically damaged by exposure to ultraviolet light. cancerization (Figure 1a) (1). In cutaneous squamous cell carcinoma (cSCC), the atypical keratinocytes break through the basal membrane; this can manifest itself with nodular growth (Figure 1b) (1). cSCC can arise de novo or on the basis of preexisting AK. The probability and speed of the transition from AK to cSCC is individual, highly variable, and unpredictable. In a systematic review, the progression rate of a single AK to $\mathrm{cSCC}$ was variably estimated at $0 \%$ to $0.075 \%$ per lesion per year. A higher progression rate of $0.53 \%$ per lesion per year was estimated if the patient already had cSCC elsewhere. At the same time, however, single AK were found to have 

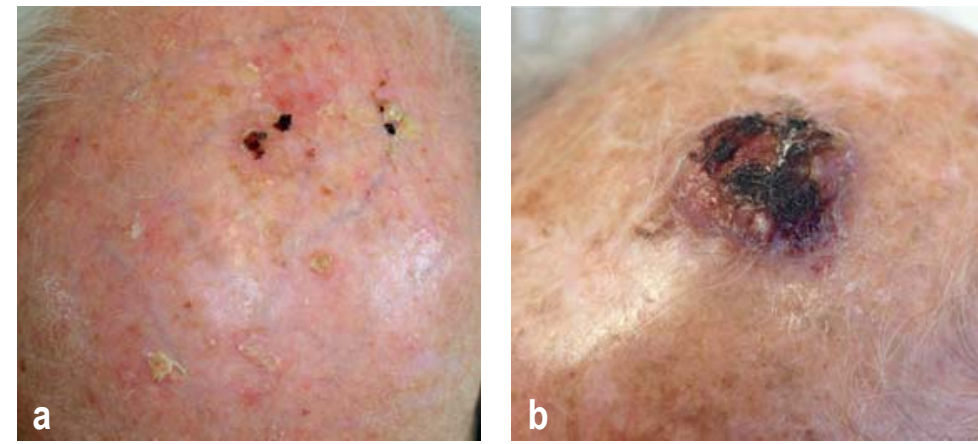

Figure 1

a) Representative illustration of field cancerization

b) Squamous cell carcinoma arising from field cancerization

c) Metastatic squamous cell carcinoma

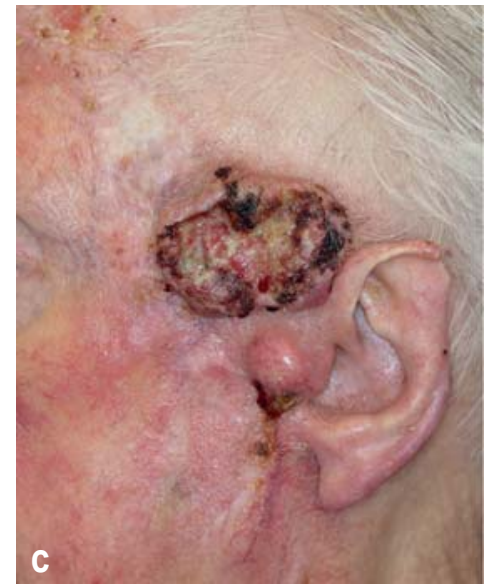

high regression rates ranging from $15 \%$ to $53 \%$ per year, as well as long-term recurrence rates above 50\% (2). In the review article, this dynamic was attributed in part to methodological weaknesses in the published studies (e.g., missing data on treatments received and on sun-screening methods, as well as high dropout rates). Yet the literature and clinical experience do, in fact, show that $\mathrm{AK}$ and light-induced skin damage are a dynamic rather than static pathological process (2).

The age-standardized incidence rate of $\mathrm{cSCC}$ in Germany in the period 2010 to 2014 was 26.90 per 100000 persons per year, which was $30 \%$ higher than the corresponding figure for 2005 to 2009 (1). After a diagnosis of cSCC, $50 \%$ of patients go on to develop further epithelial skin tumors, most often within 1 year of the initial diagnosis (1).

Cumulative UV exposure is the main risk factor for $\mathrm{AK}$ and $\mathrm{cSCC}$ (Box 1). If a patient has six or more $\mathrm{AK}$, a cSCC, or field cancerization over an area of at least $4 \mathrm{~cm}^{2}$ on a region of skin that is exposed to UV light because of the patient's work, the possible presence of an occupational disease should be assessed (no. 5103 in the German classification of occupational diseases). Immune compromise, e.g., in transplant recipients and patients with hematologic cancers such as chronic lymphocytic leukemia, is also associated with a higher incidence and a more aggressive course of cSCC (3).

The risk of recurrence and metastasis of $\mathrm{cSCC}$ is low with appropriate therapy. Clinical and histological risk factors have been determined (Box 2). In a series of 114 patients with metastatic cSCC, 46 (40\%) had locoregional metastasis in the skin and lymph

\section{Rising incidence}

The age-standardized incidence rate of cSCC in Germany in 2010 to 2014 was 26.90 per 100000 persons per year, $30 \%$ higher than the corresponding figure for 2005 to 2009. nodes (Figure 1c), 35 (31\%) had distant metastases (usually to the lungs and pleura), and 33 (29\%) had simultaneous locoregional and distant metastases (e63). Curative treatment is considered no longer possible in patients with distant metastases or a regional metastasis or local recurrence that cannot be completely controlled with surgery or radiotherapy (e63).

\section{Learning objectives}

This article is intended to enable the reader to:

- Gain an up-to-date understanding of the clinical features and prognosis of actinic keratosis and cutaneous squamous cell carcinoma

- Become familiar with the essential procedures for treatment of these lesions

- Assess the advantages and limitations of the various treatment options

\section{Methods}

This review is based on pertinent publications retrieved by a systematic review of the Medline database, as well as on the German guidelines on $\mathrm{AK}$ and $\mathrm{cSCC}$, skin cancer prevention, and histologically guided surgery. The evidence levels are taken from the assessments contained in the German clinical practice guidelines on $\mathrm{AK}$ and cSCC, which employ the system of the Oxford Center for Evidence-Based Medicine in its version of 2011 (1). Evidence levels are given on a scale from 1 to 5 , with 1 being the highest and 5 the lowest.

\section{Actinic keratosis}

It cannot yet be reliably determined on clinical and histological grounds which AK lesions will undergo 


\section{BoX 1}

\section{Risk factors for the development of actinic keratosis and cutaneous squamous cell carcinoma (8)}

- Cumulative ultraviolet light exposure

- Light skin type

- Advanced age

- Genodermatoses (e.g., epidermolysis, xeroderma)

- Chronic inflammation

- Exposure to certain toxic substances (e.g., arsenic, tar)

- Immune suppression (iatrogenic or underlying disease)

- HPV infection
Box 2

Risk factors for unfavorable outcome of cutaneous squamous cell carcinoma*

- Clinical

- Horizontal tumor size $>2 \mathrm{~cm}$

- Localization on ear or lower lip

- Immune suppression (iatrogenic/underlying disease)

- Histological

- Vertical tumor thickness $>2 \mathrm{~mm}$ (intermediate), $>6 \mathrm{~mm}$ (high)

- Histological differentiation G3/G4

- Desmoplasia

- Perineural growth

*Elevated rate of locoregional recurrence and metastasis (40, e1, e2) transformation into invasive cSCC and which will not. Important indicators of the individual risk of developing cSCC include immune suppression, a prior history of epithelial skin cancer, high cumulative UV exposure, and the number of lesions present. In view of this and the fact that $\mathrm{AK}$ is perceived as a chronic, progressive disease, adequate treatment for all cases of $\mathrm{AK}$ is recommended after critical evaluation of the patient's life expectancy, comorbidities, and individual preferences.

There are many treatments for AK (Table 1, Figure 2). Lesion-directed treatments include procedures with the scalpel (e.g., shave excision), liquid nitrogen (cryosurgery), or laser (e.g., erbium/YAG; $\mathrm{CO}_{2}$ ). These are provided directly by the physician to the patient and are appropriate for isolated, well-demarcated lesions. An advantage of the surgical approach is that it provides for histopathological control of the clinical diagnosis and the complete removal of the lesion; its disadvantages include the need for local anesthesia, bleeding, and possible scar formation. Cryosurgery and laser therapy can be performed very rapidly in experienced hands but can cause pain, blisters, and superficial wounds. Moreover, hyper- or hypopigmentation can arise during and immediately after these treatments and may be permanent. A major advantage of field-directed techniques is that they can be used to treat multiple contiguous lesions, including subclinical ones, i.e., sites of AK that cannot yet be seen or palpated. Such techniques include the topical application of agents in solution or in the form of a gel or cream, as well as photodynamic therapy (PDT). The common features of field-directed treatments are healing without scar and predominantly no more than transient local side effects such as pain, erythema, swelling, sterile pustules, erosions, and scabbing. Ten different preparations are now approved for fielddirected treatment in Germany, differing in their mechanisms of action, galenic formulation, maximal area of application, duration of application, and sideeffect profiles (Table 1). A hierarchical ranking of the available treatments is difficult, as direct comparison studies are generally lacking. Four field-directed treatments were recently compared directly with one another in an independently financed trial published in a high-ranking journal: 5-fluorouracil was found to yield the highest rate of healing at 12 months in patients with at least five lesions on the scalp (4).

The choice of a suitable treatment depends on patient-, lesion-, and treatment-specific factors (Table 2). Lesion-directed techniques can generally be carried out rapidly, but they are only effective over a small area. Field-directed techniques take a few days to months to apply and thus require high patient compliance. Some of them are not covered by health insurance in Germany (e.g., red-light PDT). Alongside the parameters listed in Table 2, the physician's experience, the patient's prior history, and the availability of treatments are further important factors that need to be considered in the choice of therapy.
Treatment options for actinic keratosis

Actinic keratosis can be treated with lesion-directed and fielddirected methods.
The choice of treatment

The choice of treatment depends on patient-, lesion-, and treatment-specific factors. 
Treatments for actinic keratosis (adapted from [1])

\begin{tabular}{|c|c|c|c|}
\hline $\begin{array}{l}\text { Lesion-directed } \\
\text { treatments }\end{array}$ & Nature and application of intervention, duration of treatment & Efficacy*1 & $\begin{array}{l}\text { Common side effects and } \\
\text { tolerability / evidence level }\end{array}$ \\
\hline Cryosurgery & $\begin{array}{l}\text { - One or two freeze-thaw cycles with liquid nitrogen }\left(-196^{\circ} \mathrm{C}\right) \\
\text { - Cold exposure of target lesions for } 15-60 \mathrm{~s} \text { ("bleaching") } \\
\text { - Open spray technique or contact technique (cryostamp, cryo- } \\
\text { probe), seconds to minutes }\end{array}$ & $\begin{array}{l}++/+++ \\
\text { Lesion-/patient-specific healing } \\
\text { rates: } \\
41.9-88 \%, 25-90.3 \%\end{array}$ & $\begin{array}{l}\text { Pain, erythema, blisters, } \\
\text { hypopigmentation } \\
\text { Evidence level: } 2 \\
\text { (immune-competent patients) } \\
\text { (e3-e8) }\end{array}$ \\
\hline Operative techniques ${ }^{* 2}$ & $\begin{array}{l}\text { - Curettage } \pm \text { electrocauterization } \\
\text { - Flat ablation (shave excision), complete excision, ca. 5-20 min }\end{array}$ & +++ & $\begin{array}{l}\text { Pain, bleeding, scarring } \\
\text { Evidence level: expert consensus }\end{array}$ \\
\hline \multirow[t]{2}{*}{ Laser techniques ${ }^{* 2}$} & $\begin{array}{l}\text { - Ablative laser techniques (e.g., } \mathrm{CO}_{2} \text {, erbium-YAG laser), } \\
\text { seconds to minutes }\end{array}$ & $\begin{array}{l}++/+++ \\
\text { Lesion-/patient-specific healing } \\
\text { rates: } \\
72.4-91.1 \%, 8-65.3 \%\end{array}$ & $\begin{array}{l}\text { Pain, erythema, erosions, } \\
\text { dyspigmentation } \\
\text { Evidence level: } 2-3 \text { (immune- } \\
\text { competent patients) }(e 9, \mathrm{e} 6)\end{array}$ \\
\hline & $\begin{array}{l}\text { - Non-ablative laser techniques } 2 \text { (e.g., Nd:YAG laser, fraction- } \\
\text { ated } 1540 \mathrm{~nm} \text { laser), seconds to minutes }\end{array}$ & ++ & \\
\hline $\begin{array}{l}\text { Field-directed } \\
\text { treatments }\end{array}$ & Nature and application of intervention, duration of treatment & Efficacy $^{* 1}$ & $\begin{array}{l}\text { Common side effects and } \\
\text { tolerability / evidence level }\end{array}$ \\
\hline $\begin{array}{l}\text { Diclofenac sodium } 3 \% \\
\text { Hyaluronic acid } 2.5 \% \text { gel }\end{array}$ & $\begin{array}{l}\text { - Cyclooxygenase- } 2 \text { inhibitor } \\
\text { - b.i.d. for } 60-90 \text { days } \\
\text { - Maximum } 8 \mathrm{~g} / \mathrm{d} \\
\text { - } 2-3 \text { months }\end{array}$ & $\begin{array}{l}++ \\
\text { Lesion-/patient-specific healing } \\
\text { rates: } \\
51.8-81.0 \%, 9-50 \%\end{array}$ & $\begin{array}{l}\text { Erythema, allergy (rare) } \\
\text { Evidence level: } 1 \text { (immune- } \\
\text { competent patients); evidence level: } \\
3 \text { (immunosuppressed patients) } \\
\text { (e10-e18) }\end{array}$ \\
\hline 5-Fluorouracil 5\% cream & $\begin{array}{l}\text { - Cytostatic agent } \\
\text { - b.i.d. for } 4 \text { weeks at most } \\
\text { - Maximum } 500 \mathrm{~cm}^{2} \\
\text { - } 4 \text { weeks }\end{array}$ & $\begin{array}{l}\text { +++/++++ } \\
\text { Lesion-/patient-specific healing } \\
\text { rates: } \\
47-94 \%, 38-96 \%\end{array}$ & $\begin{array}{l}\text { Inflammatory reactions } \\
\text { (erythema, erosions, scabbing, } \\
\text { hyperpigmentation) } \\
\text { Evidence level: } 1 \text { (4, e4, e19-e21) }\end{array}$ \\
\hline $\begin{array}{l}\text { 5-Fluorouracil } 0.5 \% \\
\text { with salicylic acid } 10 \% \\
\text { in solution }\end{array}$ & $\begin{array}{l}\text { - Cytostatic and keratolytic agent } \\
\text { - q.d. for } 6-12 \text { weeks } \\
-25 \mathrm{~cm}^{2} \\
-6-12 \text { weeks }\end{array}$ & $\begin{array}{l}+++ \\
\text { Lesion-/patient-specific healing } \\
\text { rates: } \\
39.4-98.7 \%, 55.4 \%\end{array}$ & $\begin{array}{l}\text { Inflammatory reactions } \\
\text { (erythema, erosions, scabbing, } \\
\text { hyperpigmentation) } \\
\text { Evidence level: } 2 \text { (immune- } \\
\text { competent patients) }(\mathrm{e} 12, \mathrm{e} 5)\end{array}$ \\
\hline Ingenol mebutate gel & $\begin{array}{l}\text { - Euphorbia extract (cytotoxic) } \\
-0.015 \% \text { (face and scalp): } \\
\text { q.d. on } 3 \text { consecutive days } \\
-0.050 \% \text { (trunk, limbs): } \\
\text { q.d. on } 2 \text { consecutive days } \\
-25 \mathrm{~cm}^{2} \text { in each case } \\
-2-3 \text { days }\end{array}$ & $\begin{array}{l}+++ \\
\text { Face/scalp: } \\
\text { lesion-/patient-specific healing } \\
\text { rates: } \\
62.9-87.2 \%, 36.4-61.6 \% \\
\text { Limbs/trunk: } \\
\text { lesion-/patient-specific healing } \\
\text { rates: } \\
73-100 \%, 22-54-4 \%\end{array}$ & $\begin{array}{l}\text { Inflammatory reactions } \\
\text { (erythema, erosions, scabbing) } \\
\text { Evidence level: } 1-2,(4, \text { e22-e28) }\end{array}$ \\
\hline Imiquimod $3.75 \%$ cream & $\begin{array}{l}\text { - Toll-like receptor } 7 \text { agonist } \\
\text { - q.d. for } 2 \text { weeks, then } 2 \text { week pause, then } \\
\text { q.d. for } 2 \text { weeks (interval therapy) } \\
-25-200 \mathrm{~cm}^{2} \\
-6 \text { weeks }\end{array}$ & $\begin{array}{l}+++ \\
\text { Lesion-specific healing rate: } \\
34.0-81.8 \%\end{array}$ & $\begin{array}{l}\text { Inflammatory reactions } \\
\text { (erythema, erosions, scabbing), } \\
\text { flu-like symptoms (fever), rare } \\
\text { Evidence level: } 2 \text { (immune- } \\
\text { competent patients) (e29, e30) }\end{array}$ \\
\hline Imiquimod $5 \%$ cream & $\begin{array}{l}\text { - Toll-like receptor } 7 \text { agonist } \\
-3 \times / \text { week for } 4 \text { weeks } \\
-25 \mathrm{~cm}^{2} \\
-4 \text { weeks }\end{array}$ & $\begin{array}{l}+++ \\
\text { Lesion-/patient-specific healing } \\
\text { rates: } \\
45.1-93.6 \%, 24-85 \%\end{array}$ & $\begin{array}{l}\text { Inflammatory reactions } \\
\text { (erythema, erosions, scabbing), } \\
\text { flu-like symptoms (fever), rare } \\
\text { Evidence level: } 1 \text { (immune- } \\
\text { competent patients); evidence level: } \\
2 \text { (immunosuppressed patients) (4, } \\
\text { e31-e40, e20) }\end{array}$ \\
\hline ALA cream for red light PDT & $\begin{array}{l}\text { - Protoporphyrin precursor (photosensitizer) } \\
\text { - Application of ALA, light-protective dressing for } 3 \mathrm{hr} \text { or patch for } \\
4 \mathrm{hr} \text {, red light illumination for ca. } 10-20 \mathrm{~min} \text {, may repeat in } \\
4-12 \text { weeks } \\
\text { - Alacare } 4 \mathrm{~cm}^{2} \text { (up to six patches at once), ca. } 4 \mathrm{hr}\end{array}$ & $\begin{array}{l}+++/++++ \\
\text { Lesion-/patient-specific healing } \\
\text { rates: } \\
58.0-94.3 \%, 50-91 \%\end{array}$ & $\begin{array}{l}\text { Pain, inflammatory reactions } \\
\text { (erythema, sterile pustules, ero- } \\
\text { sions, scabbing) } \\
\text { Evidence level: } 1 \text { (immune- } \\
\text { competent patients) (e41-e48) }\end{array}$ \\
\hline MAL cream for red light PDT & $\begin{array}{l}\text { - Protoporphyrin precursor (photosensitizer) } \\
\text { - Application of MAL, light-protective and occlusive dression for } \\
3 \mathrm{hr} \text {, red light illumination for ca. 10-20 min, may repeat in } \\
4-12 \text { weeks, ca. } 4 \mathrm{~h}\end{array}$ & $\begin{array}{l}+++/++++ \\
\text { Lesion-/patient-specific healing } \\
\text { rates: } \\
67.1-90.3 \%, 31.4-78 \%\end{array}$ & $\begin{array}{l}\text { Pain, inflammatory reactions } \\
\text { (erythema, sterile pustules, } \\
\text { erosions, scabbing) } \\
\text { Evidence level: } 1 \text { (immune- } \\
\text { competent patients); evidence level: } \\
3 \text { (immunosuppressed patients) (4, } \\
\text { e7, e8, e24, e43, e49-e52) }\end{array}$ \\
\hline $\begin{array}{l}\text { ALA or MAL cream for day- } \\
\text { light PDT }\end{array}$ & $\begin{array}{l}\text { - Protoporphyrin precursor (photosensitizer) } \\
\text { - Application of MAL and chemical light-protective filter, exposure } \\
\text { to sunlight for } 2 \mathrm{hr} \\
\text { - Conditions: outside temperature }>10^{\circ} \mathrm{C} \text {, cloudless or cloudy sky, } \\
\text { no rain; duration } 2.5 \mathrm{hr}\end{array}$ & $\begin{array}{l}+++ \\
\text { Lesion-/patient-specific healing } \\
\text { rates: } \\
77.2-89.2 \%, 31.8-42.9 \%\end{array}$ & $\begin{array}{l}\text { Inflammatory reactions (erythema, } \\
\text { sterile pustules, erosions, scabbing) } \\
\text { Evidence level: } 2-3 \text { (immune- } \\
\text { competent patients) (e23, e53-e55) }\end{array}$ \\
\hline
\end{tabular}

${ }^{* 1}$ Semiquantitative representation taking account of the lesion- and patient-specific response rates in randomized controlled trials $(+=$ not very effective, $++=$ moderately effective, $+++=$ effective, $++++=$ highly effective); ${ }^{* 2}$ based on expert opinion: ALA, aminolevulinic acid; MAL, methyl aminolevulinic acid; PDT, photodynamic therapy 
Combinations of treatment approaches are reasonable and are being applied more and more frequently, e.g., field-directed treatment after lesion-directed treatment. For example, laser ablation can be carried out before PDT to remove especially thick hyperkeratotic lesions, thereby making the skin surface more permeable for cream application. Other studies have shown that the combination of imiquimod and PDT leads to significantly higher healing rates than monotherapy (5-7).

\section{Cutaneous squamous cell carcinoma}

The treatment options for cSCC include surgery, radiotherapy, and medication (Table 3, Figure 2).

\section{Surgical treatment}

Complete excision under histopathological guidance is the standard treatment of cSCC. There is no commonly accepted definition of an $\mathrm{R} 0$ resection; the desired distance from the edge of the tumor to the border of the resection varies in the literature from 0 to $6 \mathrm{~mm}(8)$. After resection and until the time of definitive histopathological confirmation, the wound should only be closed if the borders of the resection will remain clearly identifiable. For tumors less than $1 \mathrm{~cm}$ in size, shaveexcision is an alternative to resection. In this situation, the diameter of the excised tissue should be no less than $5 \mathrm{~mm}$ to enable reliable histopathological examination (1). If the clinical diagnosis is unambiguously clear, excision can be carried out without prior biopsy. The risk factors for local recurrence and metastasis (Box 2) are also relevant to surgical planning, as one may want to consider wider safety margins or elective lymph node surgery (e.g., biopsy of a sentinel node) in patients at higher risk.

The technique of histopathological examination is what distinguishes conventional surgery from micrographically controlled surgery (MCS), also known as Mohs surgery (9). The latter generally involves 3D histology, i.e., once the tumor has been excised, the outer sides of the resection specimen are separately analyzed histologically to enable complete inspection of the three-dimensional edges of the resection (9). MCS allows the detection of outward extensions of the tumor with high sensitivity; consequently, the safety margin for excision can be kept relatively low. Although frozen sections are quicker to prepare, paraffin sections are superior for the detection of subclinical tumor extensions (9). MCS is to be distinguished from excision with a wide safety margin and lamellar sectioning of the specimen (the loaf-of-bread technique), in which the entire extent of the tumor is histologically examined (9). The safety margin for resection is not definitively laid down in the literature (1-4 $\mathrm{mm}$, up to $50 \mathrm{~mm}$ under certain circumstances), but the risk of subtotal resection increases with the size of the specimen and in inverse relation to the safety margin (8). The local recurrence rate after MCS ranges from 0 to $33 \%$, with rates of $2 \%$ to $8 \%$ reported in most studies. The local recurrence rate after resection with the loaf-of-bread technique ranges from $0 \%$ to $53 \%$, with numbers of $2 \%$ to $13 \%$ most commonly reported (8). No method has yet been shown to be clearly superior to any other.

The identification and excision of one or more sentinel lymph nodes (sentinel lymph node biopsy, SLNB) is an option for minimally invasive lymph node diagnosis in order to detect occult metastasis while avoiding excessive lymphadenectomy. SLNB can be considered in patients with high-risk cSCC, particularly in the head and neck region, with its variable lymphatic flow. Despite high sensitivity (79\%) and specificity $(100 \%)$ and a negative predictive value of $96 \%$ (10), SLNB of one or more nodes has not been shown to result in significantly longer disease-specific overall or metastasis-free survival $(11,12)$, and it therefore cannot be generally recommended (1). Prophylactic lymphadenectomy should not be performed $(1,13)$. In the case of clinically or histologically apparent lymph node metastasis, therapeutic lymph node dissection should be performed, as this improves locoregional tumor control $(8,13)$. The extent of the therapeutic lymph node removal has not been precisely defined; if possible, selective functional resection should be carried out (1).

Resection is also the standard treatment for locoregional recurrence, as long as the conditions for local and general operability are met.

\section{Radiotherapy}

Although there have not been any prospective, randomized trials comparing primary radiotherapy with other local treatments, retrospective studies have shown a local tumor control rate of $94.0 \%$ at 5 years with radiotherapy alone (14). A prospective phase III trial compared radiation alone with radiochemotherapy for cSCC in the head and neck region. The additional administration of carboplatin was found not to have any additional effect; the rate of locoregional tumor control at 5 years was $83 \%$ after radiotherapy and $87 \%$ after radiochemotherapy, and the rates of 5 -year overall survival were $76 \%$ and $79 \%$ (15).
The gold standard

Complete excision is the gold standard treatment for CSCC.

\section{Safety margins}

The complete excision of cSCC should be histologically confirmed. 


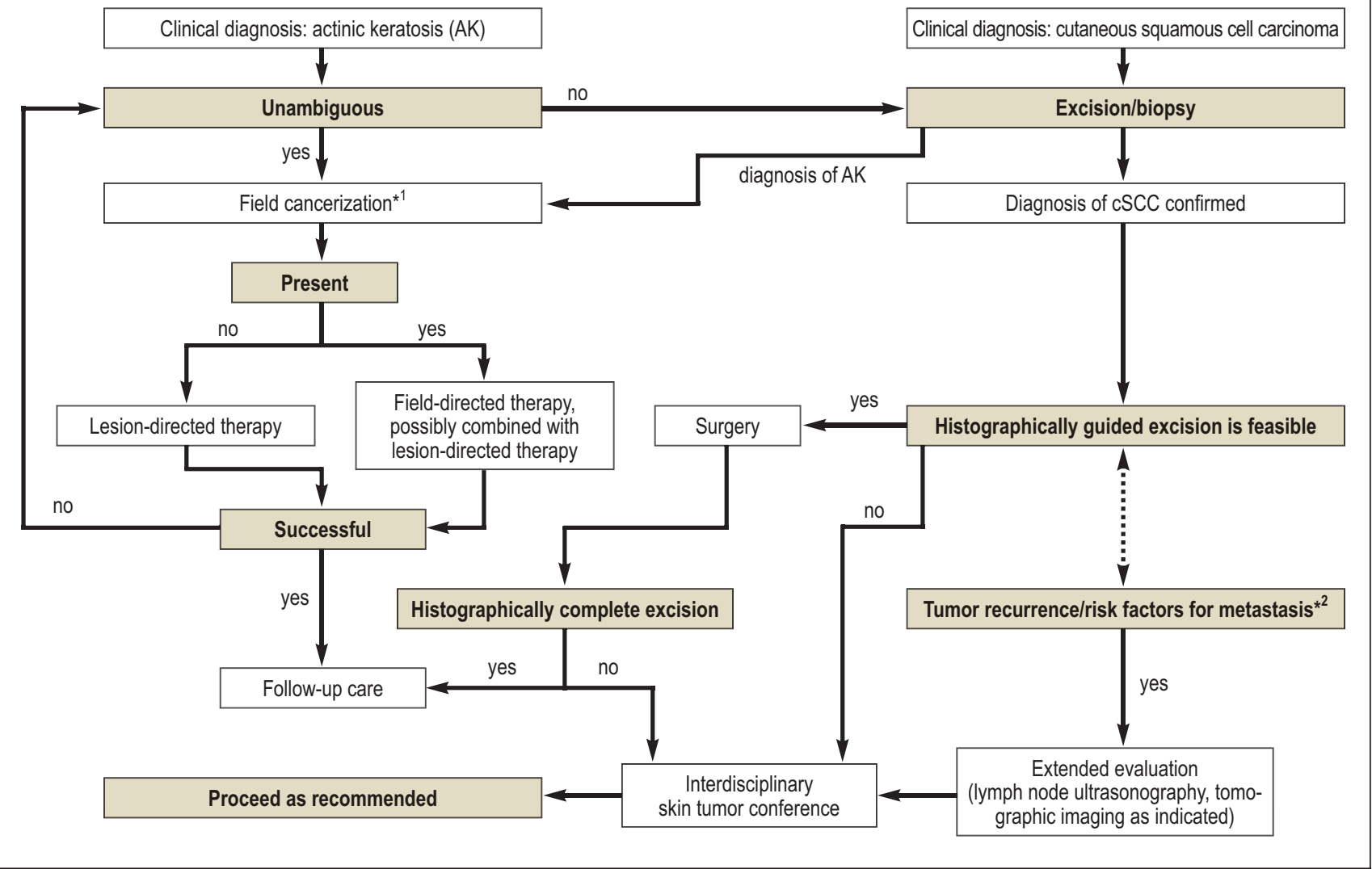

Diagnostic and therapeutic algorithm for actinic keratosis and cutaneous squamous cell carcinoma

${ }^{* 1}$ Field cancerization: multiple actinic keratoses and evidence of ultraviolet-induced damage in a contiguous area of skin

${ }^{* 2}$ Risk factors: tumor thickness $>6 \mathrm{~mm}$, or tumor thickness $>2 \mathrm{~mm}$ with additional risk factors (histologic grade $\geq \mathrm{G} 3$, perineural or desmoplastic growth, localization on lower lip or ear, immune suppression), or positive clinical finding (e.g., palpable regional lymph node enlargement)

Postoperative radiotherapy is indicated only in the presence of risk factors. These include R1 or R2 resection, a narrow resection margin $(<2 \mathrm{~mm})$, recurrent tumor, large tumor $(>2 \mathrm{~cm})$, deep tumor penetration $(>4 \mathrm{~mm})$, infiltration of adipose tissue, perineural sheath infiltration, and extensive lymphatic involvement ( $>1$ lymph node, extension beyond capsule) (16-19). Postoperative radiotherapy should be performed after R1 or R2 resection or when the resection margin is $<2 \mathrm{~mm}(1,8,17,18,20)$. The same holds for perineural sheath infiltration by tumor, although the extent of the infiltration is relevant here. If the infiltration is microscopic, the local control rate after surgery alone is $78 \%$ to $87 \%$; if it is macroscopic, the local control rate after surgery is $50 \%$ to $55 \%$, compared to $100 \%$ after postoperative radiotherapy in selected patients (19). Postoperative radiotherapy should also be performed in the case of extensive involvement of the cervical lymph nodes $(>1$ lymph node, lymph node metastasis $>3 \mathrm{~cm}$, extension beyond capsule, intraparotid lymph node involvement) $(18,21,22)$. In a retrospective study, the local recurrence rate, 5-year disease-free survival rate, and overall survival rate after surgery alone were $55 \%, 34 \%$, and $27 \%$, respectively, while the corresponding rates after surgery and postoperative radiotherapy were $23 \%, 74 \%$, and $66 \%(22)$. The procedure to be followed in the case of lymph node metastasis in the axillary or inguinal regions is analogous to the indication for postoperative radiotherapy in the head and neck

\section{Radiotherapy}

Radiotherapy should be performed if a tumor cannot be completely excised locally or is inoperable for medical reasons.

\section{Postoperative radiotherapy}

Postoperative radiotherapy is indicated if there are risk factors for local or locoregional recurrence. 


\section{Factors affecting the choice of treatment for actinic keratosis}

\begin{tabular}{l|l|l}
\hline Patient factors & Lesion factors & Treatment factors \\
- Immune suppression & - Site & - Lesion- or field-directed \\
- Comorbidities & (e.g., face, scalp, lower lip, limbs) & - Application by patient or by medical staff \\
- Medications & - Clinical consistency & - Duration of application \\
- Patient preference & (e.g., thickness of keratinization) & - Side effects \\
- Treatment compliance & - Size of lesion and of affected area & - Availability of equipment \\
& & (e.g., laser, red-light lamp) \\
& & - Cost
\end{tabular}

region. Depending on the risk constellation, radiation doses ranging from $50 \mathrm{~Gy}$ (R1 resection, resection margin $<2 \mathrm{~mm}$ ) to $66 \mathrm{~Gy}$ (R2 resection) are recommended (18). For local or locoregional recurrences, the same criteria as in the primary situation apply with respect to the indication for postoperative radiotherapy (1).

\section{Systemic drug treatment}

Systemic drugs are given when local measures no longer suffice, e.g., in the case of a locally advanced lesion (usually after prior surgery and radiotherapy) or distant metastasis. In a systematic review of the literature from the years 1970 to 2011, Behshad et al. identified 28 studies (all with low-level evidence) including 119 patients with locally advanced cSCC who were treated with systemic drugs. In a large majority of cases, various chemotherapeutic agents were used either singly, in combination, or together with radiotherapy (23). The observed overall response rate was $72 \%$, and the median response duration was 10.5 months.

In addition to chemotherapy, many publications have described the use of targeted therapies against the epidermal growth factor receptor (EGFR) to treat cSCC, but there have been only a few, uncontrolled prospective trials (24). In a trial of cetuximab on 36 patients, the response rate was $28 \%$, and the median response duration was 6.8 months (25); in a trial of panitumumab on 16 patients, the response rate was $31 \%$, and the median response duration was 6 months (26). In principle, EGFR blockers such as cetuximab can also be combined with chemotherapeutic drugs such as paclitaxel (27) or platinum derivatives (28), in a manner analogous to the treatment of mucosal squamous cell carcinoma.

Squamous cell carcinomas often express PD-L1 and contain tumor-infiltrating lymphocytes (29); thus, immune therapy targeted on PD-1 is another worthwhile approach. A single-armed trial of the anti-PD-1 antibody cemiplimab in 59 patients with metastatic squamous cell carcinoma yielded a response rate of $47 \%$, and, at the time of assessment, most of these remissions had persisted longer than 6 months (30). The European Medicines Agency (EMA) has approved cemiplimab for the treatment of inoperably advanced or metastatic cSCC. Patients with inoperable cSCC are currently being recruited for a trial of cetuximab combined with the PD-L1 antibody avelumab. The PD-1 antibodies cemiplimab and pembrolizumab are being tested in placebo-controlled studies for the adjuvant treatment of patients after resection and radiotherapy of high-risk cSCC. It is particularly important that the treatment strategy for patients with cSCC should be designed on an individual basis in consideration of the patient's age, comorbidities, and personal preferences.

\section{Special considerations for immune-suppressed patients}

Patients being treated with immune-suppressant drugs, particularly organ transplant recipients, have a markedly higher risk of developing $\mathrm{AK}$ and of progression of AK into invasive cSCC; these cSCC also show more aggressive growth than in the usual situation, with greatly elevated morbidity and mortality $(31,32)$. Organ transplant recipients have a 20 - to 50-fold elevation of the risk of developing a non-melanocytic skin cancer compared to immune-competent persons (32). The same holds for patients who are immunocompromised because of an underlying illness, particularly chronic lymphocytic leukemia. Such patients should be informed early of the elevated risk and taught how to examine themselves; they should undergo dermatological surveillance examinations at intervals depending on the risk, and any suspect lesions should be diagnosed and treated as early as possible.

\section{Drug therapy}

The available types of drug therapy are chemotherapy, antiEGFR therapy, and immune therapy targeted on PD-1.

\section{Criteria for the choice of treatment}

The treatment strategy for patients with CSCC should be designed on an individual basis in consideration of the patient's age, comorbidities, and personal preferences. 
Treatments for cutaneous squamous cell carcinoma

\begin{tabular}{|c|c|c|c|c|}
\hline Intervention & $\begin{array}{l}\text { Initial situation } \\
\text { before treatment }\end{array}$ & Efficacy & $\begin{array}{l}\text { Common side effects } \\
\text { and tolerability }\end{array}$ & $\begin{array}{l}\text { Evidence level } \\
\text { and references }\end{array}$ \\
\hline \multicolumn{5}{|l|}{ Locoregional treatments } \\
\hline $\begin{array}{l}\text { Complete excision } \\
\text { under histologic guidance }\end{array}$ & $\begin{array}{l}\text { - All primary tumors } \\
\text { - locoregional recurrences }\end{array}$ & Local recurrence rate $2-8 \%$ & $\begin{array}{l}\text { Pain, bleeding, infection, } \\
\text { scarring, functional limitation, } \\
\text { nerve injury }\end{array}$ & $\begin{array}{l}\text { Expert consensus } \\
\text { (primary tumors); evidence } \\
\text { level: } 2 \text { (recurrences) } \\
\text { (e56, e57) }\end{array}$ \\
\hline $\begin{array}{l}\text { Complete excision } \\
\text { with safety margin }\end{array}$ & $\begin{array}{l}\text { - Tumor }<20 \mathrm{~mm}: 4 \mathrm{~mm} \\
\text { safety margin } \\
\text { - Tumor } \geq 20 \mathrm{~mm}: 6-9 \mathrm{~mm} \\
\text { safety margin }\end{array}$ & Local recurrence rate $2-13 \%$ & $\begin{array}{l}\text { Pain, bleeding, infection, } \\
\text { scarring, functional limitation, } \\
\text { nerve injury }\end{array}$ & $\begin{array}{l}\text { Expert consensus } \\
\text { (e56-e58) }\end{array}$ \\
\hline Deep shave-excision & $\begin{array}{l}\text { Small tumors } \\
\text { with diameter }<1 \mathrm{~cm}\end{array}$ & $\begin{array}{l}\text { Local recurrence rate } \\
0.5-3.4 \%\end{array}$ & $\begin{array}{l}\text { Pain, bleeding, infection, } \\
\text { scarring }\end{array}$ & $\begin{array}{l}\text { Expert consensus } \\
\text { (e57) }\end{array}$ \\
\hline Radiotherapy & $\begin{array}{l}\text { - Not completely resectable } \\
\text { tumor or inoperable patient } \\
\text { - Narrow resection margin } \\
\text { (<2 mm with no possibility } \\
\text { of extending resection) or } \\
\text { extensive perineural sheath } \\
\text { infiltration }\end{array}$ & Local recurrence rate $3-11 \%$ & $\begin{array}{l}\text { Inflammation of skin and } \\
\text { mucous membranes, alopecia }\end{array}$ & $\begin{array}{l}\text { Evidence level: } 2-3 \\
\text { (e57) }\end{array}$ \\
\hline Electrochemotherapy & $\begin{array}{l}\text { Locoregional recurrence with } \\
\text { no option for excision or } \\
\text { radiotherapy }\end{array}$ & Response rate $46 \%$ & Pulmonary toxicity & $\begin{array}{l}\text { Expert consensus } \\
\text { (e59) }\end{array}$ \\
\hline \multicolumn{5}{|l|}{ Systemic treatments } \\
\hline Chemotherapy & $\begin{array}{l}\text { Tumor that cannot be } \\
\text { controlled with locoregional } \\
\text { measures }\end{array}$ & $\begin{array}{l}\text { Response rate } 72 \% \text {, } \\
\text { median response duration } \\
9-10 \text { months }\end{array}$ & $\begin{array}{l}\text { Altered blood counts, alopecia, } \\
\text { peripheral neuropathy, hand- } \\
\text { foot syndrome, nephrotoxicity }\end{array}$ & $\begin{array}{l}\text { Expert consensus } \\
(23)\end{array}$ \\
\hline EGFR blockers & $\begin{array}{l}\text { Tumor that cannot be } \\
\text { controlled with locoregional } \\
\text { measures }\end{array}$ & $\begin{array}{l}\text { Response rate } 25-45 \% \text {, } \\
\text { median response duration } \\
6-8 \text { months }\end{array}$ & $\begin{array}{l}\text { Papulo-pustular rash, } \\
\text { paronychiae, hair changes, } \\
\text { diarrhea }\end{array}$ & $\begin{array}{l}\text { Expert consensus } \\
(25,26)\end{array}$ \\
\hline PD-1 inhibitors & $\begin{array}{l}\text { Tumor that cannot be } \\
\text { controlled with locoregional } \\
\text { measures }\end{array}$ & $\begin{array}{l}\text { Response rate } 39-49 \% \\
\text { median progression-free } \\
\text { survival } 14.2-18.4 \text { months }\end{array}$ & $\begin{array}{l}\text { Autoimmune phenomena } \\
\text { (e.g., thyroiditis, colitis, } \\
\text { dermatitis, pneumonitis) }\end{array}$ & $\begin{array}{l}\text { Expert consensus } \\
(30, \text { e60-e62) }\end{array}$ \\
\hline
\end{tabular}

Data are available from randomized, controlled trials on the treatment of AK in organ transplant recipients with PDT combined with methyl aminolevulinic acid (MAL-PDT), ablative fractionated laser therapy (AFXL), diclofenac sodium 3\% gel, imiquimod 5\% cream, and 5-fluorouracil 5\% cream: healing rates were highest with MAL-PDT and lowest with AFXL (33) (Table 1). Early diagnosis and surgical resection are determinative for the successful treatment of squamous cell carcinoma (34). Radiotherapy can be used to treat advanced lesions or those with a high risk of recurrence. The drug treatments listed here must be carefully considered because of their side effects.

\section{Caveat: immunosuppression}

The incidence and aggressiveness of AK and CSCC are higher in immune-suppressed patients.
Immune therapy, in particular, can exacerbate an existing autoimmune disease or cause transplant rejection $(35,36)$.

As for iatrogenic immune suppression, multiple prospective, randomized trials carried out in kidney transplant recipients have unanimously shown that switching the immune-suppressant drug from a calcineurin inhibitor to an mTOR inhibitor in highrisk patients who have had epithelial skin tumors resected significantly lowers the risk of further skin tumors (37). This effect is greatest in patients who have had only one tumor resected, rather than two or more.
The special case of the organ transplant recipient

In organ transplant recipients with AK or CSCC, switching the immune-suppressant drug to an mTOR inhibitor can be considered. 


\section{Prophylactic measures}

In two prospective, randomized, placebo-controlled trials on patients in whom epithelial skin tumors had been resected, the development of new cSCC was shown to be significantly less common after prophylactic treatment: one study concerned topical treatment with 5\% 5-fluorouracil on the face for 2 to 4 weeks (38), and the other concerned the daily taking of $1000 \mathrm{mg}$ nicotinic acid amide/vitamin B3 (39). In both trials, however, the effect was lost once the treatment was terminated. It follows that permanent nicotinic acid amide treatment can be considered for high-risk patients. Topical treatment with 5\% 5fluorouracil can be repeated depending on the clinical course and the development of new lesions. In organ transplant recipients, switching the immunesuppressant drug to an mTOR inhibitor can be considered.

\section{Conflict of interest statement}

Prof. Gutzmer has served as a paid consultant for Roche, Bristol-Myers Squibb, Almirall Hermal, Amgen, Pierre Fabre, Merck Serono, Takeda, SUN, ASC, Incyte, Pfizer, Sanofi, and Novartis. He has received lecture honoraria from Roche, Bristol-Myers Squibb, MSD, Novartis, Amgen, Pierre Fabre, Merck-Serono, Almirall, AstraZeneca, Sanofi, and SUN. He has received reimbursement of congress participation fees and travel expenses from Merck-Serono, Pierre Fabre, BMS, Roche, and SUN. He has received funding from Novartis, Amgen, Merck-Serono, Pfizer, and Johnson \& Johnson for a research project that he initiated.

Prof. Wiegand has served as a paid consultant for Bristol-Myers Squibb and MSD. She has received lecture honoraria from Astra Zeneca, MSD, Merck-Serono, and Bristol-Myers Squibb. She has received reimbursement of travel and accommodation expenses from Astra Zeneca, MSD, and Bristol-Myers Squibb.

PD Wermker has served as a paid member of an Advisory Board for Bristol-Myers Squibb.

Dr. Heppt has served as a paid consultant for Sanofi-Aventis

Prof. Berking has served as a paid consultant for Almirall Hermal, Galderma, Leo Pharma, MSD, and Sanofi-Aventis. She has received lecture honoraria from Leo Pharma and Galderma. She has received funding from Leo Pharma for a research project that she initiated and third-party research funding from Biofrontera.

Prof. Kölbl states that he has no conflict of interest.

Manuscript submitted on 29 March 2019, revised version accepted on 4 July 2019

Translated from the original German by Ethan Taub, M.D.

\section{References}

1. Deutsche Krebsgesellschaft DKG, AWMF: S3-Leitlinie Aktinische Keratose und Plattenepithelkarzinom der Haut. Langversion 1.0. www.awmf. org/uploads/tx_szleitlinien/032-022OLk_S3_Aktinische_Keratosen-Plattenepithelkarzinom-PEK_2019-07.pdf (last accessed on 3 August 2019).

2. Werner RN, Sammain A, Erdmann R, Hartmann V, Stockfleth E, Nast A: The natural history of actinic keratosis: a systematic review. Br J Dermatol 2013; 169: 502-18.

3. Hillen U, Ulrich M, Alter M, et al.: [Cutaneous squamous cell carcinoma: a review with consideration of special patient groups]. Hautarzt 2014; 65: $590-9$.
4. Jansen MHE, Kessels J, Nelemans PJ, et al.: Randomized trial of four treatment approaches for actinic keratosis. N Engl J Med 2019; 380 : 935-46.

5. Heppt MV, Steeb T, Leiter U, Berking C: Efficacy of photodynamic therapy combined with topical interventions for the treatment of actinic keratosis: a meta-analysis. J Eur Acad Dermatol Venereol 2019; 33: $863-73$

6. Heppt MV, Steeb T, Ruzicka T, Berking C: Cryosurgery combined with topical interventions for actinic keratosis: a systematic review and meta-analysis. Br J Dermatol 2019; 180: 740-8.

7. Steeb T, Schlager JG, Kohl C, Ruzicka T, Heppt MV, Berking C: Laserassisted photodynamic therapy for actinic keratosis: a systematic review and meta-analysis. J Am Acad Dermatol 2019; 80: 947-56.

8. Stratigos A Garbe C Lebbe $C$, et al: Diagnosis and treatment of invasive squamous cell carcinoma of the skin: European consensusbased interdisciplinary guideline. Eur J Cancer 2015; 51: 1989-2007.

9. Loser CR, Rompel R, Mohrle M, et al.: S1 guideline: microscopically controlled surgery. J Dtsch Dermatol Ges 2015; 13: 942-51.

10. Allen JE, Stolle LB: Utility of sentinel node biopsy in patients with highrisk cutaneous squamous cell carcinoma. Eur J Surg Oncol 2015; 41: 197-200.

11. Leiter U, Gutzmer R, Alter $M$, et al.: [Cutaneous squamous cell carcinoma]. Hautarzt 2016; 67: 857-66.

12. Krediet JT, Beyer M, Lenz K, et al.: Sentinel lymph node biopsy and risk factors for predicting metastasis in cutaneous squamous cell carcinoma. Br J Dermatol 2015; 172: 1029-36.

13. Newlands C, Currie R, Memon A, Whitaker S, Woolford T: Nonmelanoma skin cancer: United Kingdom national multidisciplinary guidelines. J Laryngol Otol 2016; 130: 125-32.

14. Mendenhall WM, Amdur RJ, Hinerman RW, et al.: Skin cancer of the head and neck with perineural invasion. Am J Clin Oncol 2007; 30: 93-6.

15. Porceddu SV, Bressel M, Poulsen MG et al: Postoperative concurrent chemoradiotherapy versus postoperative radiotherapy in high-risk cutaneous squamous cell carcinoma of the head and neck: the randomized phase III TROG 05.01 trial. J Clin Oncol 2018; 36: 1275-83.

16. Erkan S, Savundra JM, Wood B, Acharya AN, Rajan GP: Clinical perineural invasion of the trigeminal and facial nerves in cutaneous head and neck squamous cell carcinoma: outcomes and prognostic implications of multimodality and salvage treatment. Head Neck 2017; 39: 1280-6.

17. Jambusaria-Pahlajani A, Miller CJ, Quon H, Smith N, Klein RQ, Schmults CD: Surgical monotherapy versus surgery plus adjuvant radiotherapy in high-risk cutaneous squamous cell carcinoma: a systematic review of outcomes. Dermatol Surg 2009; 35: 574-85

18. Veness MJ: Treatment recommendations in patients diagnosed with high-risk cutaneous squamous cell carcinoma. Australas Radiol 2005; 49: $365-76$

19. Han A, Ratner D: What is the role of adjuvant radiotherapy in the treatment of cutaneous squamous cell carcinoma with perineural invasion? Cancer 2007; 109: 1053-9.

20. Tanvetyanon T, Padhya T, McCaffrey J, et al.: Postoperative concurrent chemotherapy and radiotherapy for high-risk cutaneous squamous cell carcinoma of the head and neck. Head Neck 2015; 37: 840-5.

21. Amoils M, Lee CS, Sunwoo J, et al.: Node-positive cutaneous squamous cell carcinoma of the head and neck: survival, high-risk features, and adjuvant chemoradiotherapy outcomes. Head Neck 2017; 39 $881-5$.

22. Wang JT, Palme CE, Morgan GJ, Gebski V, Wang AY, Veness MJ: Predictors of outcome in patients with metastatic cutaneous head and neck squamous cell carcinoma involving cervical lymph nodes: improved survival with the addition of adjuvant radiotherapy. Head Neck 2012; 34: 1524-8.

23. Behshad R, Garcia-Zuazaga J, Bordeaux JS: Systemic treatment of locally advanced nonmetastatic cutaneous squamous cell carcinoma: a review of the literature. Br J Dermatol 2011; 165: 1169-77.

\section{Prophylaxis}

In organ transplant recipients, switching the immune suppressant drug to an mTOR inhibitor can be considered. 
24. Hitt $\mathrm{R}$, Irigoyen $\mathrm{A}$, Cortes-Funes $\mathrm{H}$, et al.: Phase II study of the combination of cetuximab and weekly paclitaxel in the first-line treatment of patients with recurrent and/or metastatic squamous cell carcinoma of head and neck. Ann Oncol 2012; 23: 1016-22.

25. Vermorken JB, Mesia R, Rivera F, et al.: Platinum-based chemotherapy plus cetuximab in head and neck cancer. N Engl J Med 2008; 359: 1116-27.

26. Schaper K, Kother B, Hesse K, Satzger I, Gutzmer R: The pattern and clinicopathological correlates of programmed death-ligand 1 expression in cutaneous squamous cell carcinoma. Br J Dermatol 2017; 176: 1354-6.

27. Migden MR, Rischin D, Schmults CD, et al.: PD-1-Blockade with Cemiplimab in advanced cutaneous squamous-cell carcinoma. N Engl J Med 2018; 379: 341-51.

28. Euvrard S, Kanitakis J, Claudy A: Skin cancers after organ transplantation. N Engl J Med 2003; 348: 1681-91.

29. Ulrich C, Arnold R, Frei U, Hetzer R, Neuhaus P, Stockfleth E: Skin changes following organ transplantation: an interdisciplinary challenge. Dtsch Arztebl Int 2014; 111: 188-94.

30. Heppt MV, Steeb T, Niesert AC, et al.: Local interventions for actinic keratosis in organ transplant recipients: a systematic review. Br J Dermatol 2019; 180: 43-50.

31. Cheng JY, Li FY, Ko CJ, Colegio OR: Cutaneous squamous cell carcinomas in solid organ transplant recipients compared with immunocompetent patients. JAMA Dermatol 2018; 154: 60-6.

32. Tio M, Rai R, Ezeoke OM, et al.: Anti-PD-1/PD-L1 immunotherapy in patients with solid organ transplant, HIV or hepatitis B/C infection. Eur J Cancer 2018; 104: 137-44.

33. Gutzmer R, Koop A, Meier F, et al.: Programmed cell death protein-1 (PD-1) inhibitor therapy in patients with advanced melanoma and preexisting autoimmunity or ipilimumab-triggered autoimmunity. Eur J Cancer 2017; 75: 24-32.
34. Alter M, Satzger I, Schrem H, Kaltenborn A, Kapp A, Gutzmer R: Non-melanoma skin cancer is reduced after switch of immunosuppression to mTOR-inhibitors in organ transplant recipients. J Dtsch Dermatol Ges 2014; 12: 480-8.

35. Weinstock MA, Thwin SS, Siegel JA, et al.: Chemoprevention of basal and squamous cell carcinoma with a single course of fluorouracil, $5 \%$, cream: a randomized clinical trial. JAMA Dermatol 2018; 154: 167-74.

36. Chen AC, Martin AJ, Choy B, et al:: A phase 3 randomized trial of nicotinamide for skin-cancer chemoprevention. N Engl J Med 2015; 373: 1618-26.

37. Brantsch KD, Meisner C, Schonfisch B, et al.: Analysis of risk factors determining prognosis of cutaneous squamous-cell carcinoma: a prospective study. Lancet Oncol 2008; 9: 713-20.

\section{Corresponding author}

Prof. Dr. med. Ralf Gutzmer

Hauttumorzentrum Hannover

Klinik für Dermatologie, Allergologie und Venerologie

Medizinische Hochschule Hannover (MHH)

Carl Neuberg Str. 1

30625 Hannover, Germany

Gutzmer.Ralf@mh-hannover.de

\section{Cite this as:}

Gutzmer R, Wiegand S, Kölbl O, Wermker K, Heppt M, Berking C:

Actinic keratosis and cutaneous squamous carcinoma-treatment options.

Dtsch Arztebl Int 2019; 116: 616-26; DOI: 10.3238/arztebl.2019.0616

\section{Supplementary material}

For eReferences please refer to: www.aerzteblatt-international.de/ref3719

\section{Further information on CME}

- Participation in the CME certification program is possible only over the Internet: cme.aerzteblatt.de. This unit can be accessed until 8 December 2019.

- Submissions by letter, e-mail or fax cannot be considered.

- The ffollowing CME units can still be accessed for credit:

- "Psychopharmacological Treatment in Older People" (issue 29-30/2019) until 13 October 2019

- "Benign Breast Disease in Women" (issue 33/2019) until 10 November 2019

- This article has been certified by the North Rhine Academy for Continuing Medical Education. Participants in the CME program can manage their CME points with their 15-digit "uniform CME number" (einheitliche Fortbildungsnummer, EFN), which is found on the CME card (8027XXXXXXXXXXX). The EFN must be stated during registration on www.aerzteblatt.de ("Mein DÄ") or else entered in "Meine Daten," and the participant must agree to communication of the results. 


\section{CME credit for this unit can be obtained via cme.aerzteblatt.de until 8 December 2019.}

Only one answer is possible per question. Please select the answer that is most appropriate.

Question 1

Which of the following is a risk factor for the occurrence of actinic keratoses and cutaneous squamous cell carcinoma?
a) Female sex
b) Pregnancy
c) Young age
d) Dark skin type
e) Chronic exposure to ultraviolet light

\section{Question 2}

What histological finding is associated with an unfavorable prognosis of cutaneous squamous cell carcinoma?

a) Vertical tumor thickness $<0.5 \mathrm{~mm}$ (intermediate) $<4.5 \mathrm{~mm}$ (high)

b) Vertical tumor thickness $<1 \mathrm{~mm}$ (intermediate) $<5 \mathrm{~mm}$ (high)

c) Vertical tumor thickness $<1.5 \mathrm{~mm}$ (intermediate) $<5.5 \mathrm{~mm}$ (high)

d) Vertical tumor thickness $>2 \mathrm{~mm}$ (intermediate) $>6 \mathrm{~mm}$ (high)

e) Vertical tumor thickness $<2 \mathrm{~mm}$ (intermediate) $<6 \mathrm{~mm}$ (high)

\section{Question 3}

In what method are all of the edges of the resection examined histologically without exception, so that narrower safety margins can be chosen?
a) Punch biopsy
b) Puncture cytology
c) Micrographically controlled histology (3D histology)
d) Hematoxylin and eosin (H\&E) stain
e) Elastica-van Gieson (EvG) stain

\section{Question 4}

When should sentinel lymph node excision be considered as part of the treatment of a cutaneous squamous cell carcinoma of the head and neck region?
a) Always
b) In young patients without comorbidities
c) In patients without any already manifest lymph node metastases
d) On the initial diagnosis of actinic keratosis
e) In high-risk cSCC, especially in the head and neck region

\section{Question 5}

Which of the following is a risk factor for local or locoregional recurrence and is thus among the criteria for the indication of postoperative radiotherapy?
a) More than one involved lymph node
b) Localization on the upper arm
c) Only mild lymphatic involvement
d) Tumor depth $<2 \mathrm{~mm}$
e) Lymphadenitis colli

Question 6

Which of the following measures should be considered after the resection of a cutaneous squamous cell carcinoma from an organ transplant recipient?
a) Switching the immune suppressant drug to an mTOR inhibitor
b) Chemotherapy
c) Ablative fractionated laser therapy 3 times a week
d) Daily topical treatment of the site with ingenol mebutate gel
e) Increasing the immunosuppressive therapy

Question 7

How much higher is the risk of non-melanocytic skin cancer in an organ transplant recipient than in an immune-competent person?
a) 10 to 40 times higher
b) 20 to 50 times higher
c) 30 to 60 times higher
d) 40 to 70 times higher
e) 50 to 80 times higher

Question 8

How did the age-standardized incidence of cutaneous squamous cell carcinoma in Germany change from the period 2005 to 2009 to the period 2010 to 2014 ?
a) $10 \%$ decrease
b) $15 \%$ increase
c) $30 \%$ increase
d) $5 \%$ decrease
e) $50 \%$ increase

Question 9

Which of the following factors is relevant to occupationally associated skin cancer and makes a report to the relevant German authority mandatory (occupational disease category no. 5103)?

a) Longstanding occupational exposure to ultraviolet light

b) A light skin type

c) The appearance of two actinic keratoses within 2 years

d) Squamous cell carcinoma on the sole of the foot

e) Field cancerization $<2 \mathrm{~cm}^{2}$

Question 10

A 74-year-old kidney transplant recipient presents with an ulcerating tumor $2.5 \mathrm{~cm}$ in size on the left nostril extending onto the adjacent area of the cheek. A biopsy has already yielded the histopathological finding of a poorly differentiated squamous cell carcinoma, G3, with perineural invasion (Pn1), Breslow tumor thickness $6.8 \mathrm{~mm}$. What is the treatment of first choice?

a) In the same operation in which the tumor is resected, the defect should be directly reconstructed with a locoregional plastic-surgical flap, even if the $R$ status cannot yet be determined.

b) Complete excision under histopathological guidance with examination of all resection edges (micrographic surgery) and plastic-surgical defect reconstruction after histologically confirmed $\mathrm{RO}$ resection

c) Locoregional photodynamic therapy

d) In the same procedure as the tumor resection, radical lymphadenectomy of the neck (neck dissection) should be performed.

e) Local topical treatment with imiquimod 
Supplementary material to:

\title{
Actinic Keratosis and Cutaneous Squamous Cell Carcinoma
}

\author{
Treatment Options
}

by Ralf Gutzmer, Susanne Wiegand, Oliver Kölbl, Kai Wermker, Markus Hepp, and Carola Berking

Dtsch Arztebl Int 2019; 116: 616-26; DOI: 10.3238/arztebl.2019.0616

\section{eReferences}

e1. Wermker K, Belok F, Schipmann S, Klein M, Schulze HJ, Hallermann C: Prediction model for lymph node metastasis and recommendations for elective neck dissection in lip cancer. J Craniomaxillofac Surg 2015; 43: 545-52.

e2. Wermker K, Kluwig J, Schipmann S, Klein M, Schulze HJ, Hallermann C: Prediction score for lymph node metastasis from cutaneous squamous cell carcinoma of the external ear. Eur J Surg Oncol 2015; 41: 128-35.

e3. Foley P, Merlin K, Cumming S, et al.: A comparison of cryotherapy and imiquimod for treatment of actinic keratoses: lesion clearance, safety, and skin quality outcomes. J Drugs Dermatol 2011; 10 : 1432-8.

e4. Krawtchenko N, Roewert-Huber J, Ulrich M, Mann I, Sterry W, Stockfleth E: A randomised study of topical $5 \%$ imiquimod vs. topical 5-fluorouracil vs. cryosurgery in immunocompetent patients with actinic keratoses: a comparison of clinical and histological outcomes including 1-year follow-up. Br J Dermatol 2007; 157(Suppl 2): 34-40.

e5. Simon JC, Dominicus R, Karl L, Rodriguez R, Willers C, Dirschka T: A prospective randomized exploratory study comparing the efficacy of once-daily topical $0.5 \% 5$-fluorouracil in combination with $10.0 \%$ salicylic acid (5-FU/SA) vs. cryosurgery for the treatment of hyperkeratotic actinic keratosis. J Eur Acad Dermatol Venereol 2015; 29 : 881-9.

e6. Zane C, Facchinetti E, Rossi MT, Specchia C, Ortel B, CalzavaraPinton P: Cryotherapy is preferable to ablative $\mathrm{CO}$ laser for the treatment of isolated actinic keratoses of the face and scalp: a randomized clinical trial. Br J Dermatol 2014; 170: 1114-21.

e7. Kaufmann R, Spelman L, Weightman W, et al.: Multicentre intraindividual randomized trial of topical methyl aminolaevulinate-photodynamic therapy vs. cryotherapy for multiple actinic keratoses on the extremities. Br J Dermatol 2008; 158: 994-9.

e8. Morton C, Campbell S, Gupta G, et al.: Intraindividual, right-left comparison of topical methyl aminolaevulinate-photodynamic therapy and cryotherapy in subjects with actinic keratoses: a multicentre, randomized controlled study. Br J Dermatol 2006; 155: 1029-36.

e9. Ostertag JU, Quaedvlieg PJ, van der Geer S, et al.: A clinical comparison and long-term follow-up of topical 5-fluorouracil versus laser resurfacing in the treatment of widespread actinic keratoses. Lasers Surg Med 2006; 38: 731-9.

e10. McEwan LE, Smith JG: Topical diclofenac/hyaluronic acid gel in the treatment of solar keratoses. Australas J Dermatol 1997; 38: 187-9.

e11. Pflugfelder A, Welter AK, Leiter $U$, et al.: Open label randomized study comparing 3 months vs. 6 months treatment of actinic keratoses with $3 \%$ diclofenac in $2.5 \%$ hyaluronic acid gel: a trial of the German Dermatologic Cooperative Oncology Group. J Eur Acad Dermatol Venereol 2012; 26: 48-53.

e12. Stockfleth E, Kerl H, Zwingers T, Willers C: Low-dose 5-fluorouracil in combination with salicylic acid as a new lesion-directed option to treat topically actinic keratoses: histological and clinical study results. Br J Dermatol 2011; 165: 1101-8.

e13. Ulrich C, Johannsen A, Rowert-Huber J, Ulrich M, Sterry W, Stockfleth E: Results of a randomized, placebo-controlled safety and efficacy study of topical diclofenac 3\% gel in organ transplant patients with multiple actinic keratoses. Eur J Dermatol 2010; 20: 482-8.

e14. Wolf JE, Jr., Taylor JR, Tschen E, Kang S: Topical 3.0\% diclofenac in $2.5 \%$ hyaluronan gel in the treatment of actinic keratoses. Int J Dermatol 2001; 40: 709-13.

e15. Zane C, Facchinetti E, Rossi MT, Specchia C, Calzavara-Pinton PG: A randomized clinical trial of photodynamic therapy with methyl aminolaevulinate vs. diclofenac $3 \%$ plus hyaluronic acid gel for the treatment of multiple actinic keratoses of the face and scalp. $\mathrm{Br} \mathrm{J}$ Dermatol 2014; 170: 1143-50. e16. Gebauer K, Brown P, Varigos G: Topical diclofenac in hyaluronan gel for the treatment of solar keratoses. Australas J Dermatol 2003; 44: 40-3.

e17. Rivers JK, Arlette J, Shear N, Guenther L, Carey W, Poulin Y: Topical treatment of actinic keratoses with $3.0 \%$ diclofenac in $2.5 \%$ hyaluronan gel. Br J Dermatol 2002; 146: 94-100.

e18. Stockfleth $E$, Zwingers T, Willers C: Recurrence rates and patient assessed outcomes of $0.5 \% 5$-fluorouracil in combination with salicylic acid treating actinic keratoses. Eur J Dermatol 2012; 22: 370-4.

e19. Pomerantz H, Hogan D, Eilers D, et al.: Long-term efficacy of topica fluorouracil cream, $5 \%$, for treating actinic keratosis: a randomized clinical trial. JAMA Dermatol 2015; 151: 952-60.

e20. Tanghetti E, Werschler P: Comparison of 5\% 5-fluorouracil cream and $5 \%$ imiquimod cream in the management of actinic keratoses on the face and scalp. J Drugs Dermatol 2007; 6: 144-7.

e21. Loven K, Stein L, Furst K, Levy S: Evaluation of the efficacy and tolerability of $0.5 \%$ fluorouracil cream and $5 \%$ fluorouracil cream applied to each side of the face in patients with actinic keratosis. Clin Ther 2002; 24: 990-1000.

e22. Garbe C, Basset-Seguin N, Poulin Y, et al.: Efficacy and safety of follow-up field treatment of actinic keratosis with ingenol mebutate $0.015 \%$ gel: a randomized, controlled 12 -month study. $\mathrm{Br} \mathrm{J}$ Dermato 2016; 174: 505-13.

e23. Moggio E, Arisi M, Zane C, Calzavara-Pinton I, Calzavara-Pinton P. A randomized split-face clinical trial analyzing daylight photodynamic therapy with methyl aminolaevulinate vs ingenol mebutate gel for the treatment of multiple actinic keratoses of the face and the scalp. Photodiagnosis Photodyn Ther 2016; 16: 161-5.

e24. Zane C, Fabiano A, Arisi M, Calzavara-Pinton P: A randomized splitface clinical trial of photodynamic therapy with methyl aminolevulinate versus ingenol mebutate gel for the treatment of multiple actinic keratoses of the face and scalp. Dermatology 2016; 232: 472-7.

e25. Lebwohl M, Swanson N, Anderson LL, Melgaard A, Xu Z, Berman B: Ingenol mebutate gel for actinic keratosis. N Engl J Med 2012; 366: 1010-9.

e26. Lebwohl M, Shumack S, Stein Gold L, Melgaard A, Larsson T, Tyring SK: Long-term follow-up study of ingenol mebutate gel for the treatment of actinic keratoses. JAMA Dermatol 2013; 149: 666-70.

e27. Sinnya S, Tan JM, Prow TW, et al.: A randomized, phase lla exploratory trial to assess the safety and preliminary efficacy of LEO 43204 in patients with actinic keratosis. Br J Dermatol 2016; 174: 305-11.

e28. Anderson L, Schmieder GJ, Werschler WP, et al.: Randomized, double-blind, double-dummy, vehicle-controlled study of ingenol mebutate gel $0.025 \%$ and $0.05 \%$ for actinic keratosis. J Am Acad Dermatol 2009; 60: 934-43.

e29. Hanke CW, Beer KR, Stockfleth E, Wu J, Rosen T, Levy S: Imiqui$\bmod 2.5 \%$ and $3.75 \%$ for the treatment of actinic keratoses: results of two placebo-controlled studies of daily application to the face and balding scalp for two 3-week cycles. J Am Acad Dermatol 2010; 62: 573-81.

e30. Swanson N, Abramovits W, Berman B, Kulp J, Rigel DS, Levy S: Imiquimod $2.5 \%$ and $3.75 \%$ for the treatment of actinic keratoses: results of two placebo-controlled studies of daily application to the face and balding scalp for two 2-week cycles. J Am Acad Dermatol 2010; 62: 582-90.

e31. Alomar A, Bichel J, McRae S: Vehicle-controlled, randomized double-blind study to assess safety and efficacy of imiquimod $5 \%$ cream applied once daily 3 days per week in one or two courses of treatment of actinic keratoses on the head. Br J Dermatol 2007; 157: 133-41.

e32. Chen K, Yap LM, Marks R, Shumack S: Short-course therapy with imiquimod $5 \%$ cream for solar keratoses: a randomized controlled trial. Australas J Dermatol 2003; 44: 250-5. 
33. Jorizzo J, Dinehart S, Matheson $\mathrm{R}$, et al : Vehicle-controlled, doubleblind, randomized study of imiquimod $5 \%$ cream applied 3 days per week in one or two courses of treatment for actinic keratoses on the head. J Am Acad Dermatol 2007; 57: 265-8.

e34. Korman N, Moy R, Ling M, et al.: Dosing with $5 \%$ imiquimod cream 3 times per week for the treatment of actinic keratosis: results of two phase 3, randomized, double-blind, parallel-group, vehicle-controlled trials. Arch Dermatol 2005; 141: 467-73.

e35. Kose O, Koc E, Erbil AH, Caliskan E, Kurumlu Z: Comparison of the efficacy and tolerability of $3 \%$ diclofenac sodium gel and $5 \%$ imiquimod cream in the treatment of actinic keratosis. J Dermatolog Treat 2008; 19: 159-63.

e36. Lebwohl M, Dinehart S, Whiting D, et al.: Imiquimod $5 \%$ cream for the treatment of actinic keratosis: results from two phase III, randomized, double-blind, parallel group, vehicle-controlled trials. J Am Acad Dermatol 2004; 50: 714-21.

e37. Ooi T, Barnetson RS, Zhuang L, et al.: Imiquimod-induced regression of actinic keratosis is associated with infiltration by T lymphocytes and dendritic cells: a randomized controlled trial. $\mathrm{Br} \mathrm{J}$ Dermatol 2006; 154: 72-8.

e38. Stockfleth E, Meyer T, Benninghoff B, et al.: A randomized, doubleblind, vehicle-controlled study to assess $5 \%$ imiquimod cream for the treatment of multiple actinic keratoses. Arch Dermatol 2002 138: 1498-502.

e39. Szeimies RM, Gerritsen MJ, Gupta G, et al.: Imiquimod 5\% cream for the treatment of actinic keratosis: results from a phase III, randomized, double-blind, vehicle-controlled, clinical trial with histology. J Am Acad Dermatol 2004; 51: 547-55.

e40. Ulrich C, Bichel J, Euvrard S, et al.: Topical immunomodulation under systemic immunosuppression: results of a multicentre, randomized, placebo-controlled safety and efficacy study of imiquimod $5 \%$ cream for the treatment of actinic keratoses in kidney, heart, and liver transplant patients. Br J Dermatol 2007; 157(Suppl 2): 25-31.

e41. Smith S, Piacquadio D, Morhenn V, Atkin D, Fitzpatrick R: Short incubation PDT versus 5-FU in treating actinic keratoses. J Drugs Dermatol 2003; 2: 629-35.

e42. Szeimies RM, Radny P, Sebastian M et al: Photodynamic therapy with BF-200 ALA for the treatment of actinic keratosis: results of a prospective, randomized, double-blind, placebo-controlled phase III study. Br J Dermatol 2010; 163: 386-94.

e43. Dirschka T, Radny P, Dominicus R, et al.: Photodynamic therapy with BF-200 ALA for the treatment of actinic keratosis: results of multicentre, randomized, observer-blind phase III study in comparison with a registered methyl-5-aminolaevulinate cream and placebo. Br J Dermatol 2012; 166: 137-46.

e44. Holzer G, Pinkowicz A, Radakovic S, Schmidt JB, Tanew A: Randomized controlled trial comparing $35 \%$ trichloroacetic acid peel and 5-aminolaevulinic acid photodynamic therapy for treating multiple actinic keratosis. Br J Dermatol 2017; 176: 1155-61.

e45. Jeffes EW, McCullough JL, Weinstein GD, Kaplan R, Glazer SD, Taylor JR: Photodynamic therapy of actinic keratoses with topical aminolaevulinic acid hydrochloride and fluorescent blue light. J Am Acad Dermatol 2001; 45: 96-104.

e46. Moloney FJ, Collins P: Randomized, double-blind, prospective study to compare topical 5-aminolaevulinic acid methylester with topical 5-aminolevulinic acid photodynamic therapy for extensive scalp actinic keratosis. Br J Dermatol 2007; 157: 87-91.

e47. Piacquadio DJ, Chen DM, Farber HF, et al.: Photodynamic therapy with aminolevulinic acid topical solution and visible blue light in the treatment of multiple actinic keratoses of the face and scalp: investigator-blinded, phase 3, multicenter trials. Arch Dermatol 2004; 140: 41-6.

e48. Reinhold U, Dirschka T, Ostendorf $\mathrm{R}$, et al.: A randomized, doubleblind, phase III, multicentre study to evaluate the safety and efficacy of BF-200 ALA (Ameluz ( $\left.{ }^{\circledR}\right)$ ) vs. placebo in the field-directed treatment of mild-to-moderate actinic keratosis with photodynamic therapy (PDT) when using the BF-RhodoLED(®) lamp. Br J Dermatol 2016; 175: 696-705.

e49. Pariser DM, Lowe NJ, Stewart DM, et al.: Photodynamic therapy with topical methyl aminolevulinate for actinic keratosis: results of a prospective randomized multicenter trial. J Am Acad Dermatol 2003, 48: 227-32.

e50. Pariser D, Loss $\mathrm{R}$, Jarratt $\mathrm{M}$, et al.: Topical methyl-aminolevulinate photodynamic therapy using red light-emitting diode light for treatment of multiple actinic keratoses: a randomized, double-blind, placebo-controlled study. J Am Acad Dermatol 2008; 59: 569-76.

e51. Szeimies RM, Matheson RT, Davis SA, et al.: Topical methyl aminolevulinate photodynamic therapy using red light-emitting diode light for multiple actinic keratoses: a randomized study. Dermatol Surg 2009; 35: 586-92.

e52. Dragieva G, Prinz BM, Hafner J, et al: A randomized controlled clinical trial of topical photodynamic therapy with methyl aminolaevulinate in the treatment of actinic keratoses in transplant recipients. Br J Dermatol 2004; 151: 196-200.

e53. Neittaanmaki-Perttu N, Gronroos M, Karppinen T, Snellman E, Rissanen $\mathrm{P}$ : Photodynamic therapy for actinic keratoses: a randomized prospective non-sponsored cost-effectiveness study of daylightmediated treatment compared with light-emitting diode treatment. Acta Derm Venereol 2016; 96: 241-4.

e54. Wiegell SR, Haedersdal M, Eriksen P, Wulf HC: Photodynamic therapy of actinic keratoses with $8 \%$ and $16 \%$ methyl aminolaevulinate and home-based daylight exposure: a double-blinded randomized clinical trial. Br J Dermatol 2009; 160: 1308-14.

e55. Wiegell SR, Fabricius S, Stender IM, et al:: A randomized, multicentre study of directed daylight exposure times of $1(1 / 2)$ vs. 2(1/2) $\mathrm{h}$ in daylight-mediated photodynamic therapy with methyl aminolaevulinate in patients with multiple thin actinic keratoses of the face and scalp. Br J Dermatol 2011; 164: 1083-90.

e56. Chren MM, Linos E, Torres JS, Stuart SE, Parvataneni R, Boscardin WJ: Tumor recurrence 5 years after treatment of cutaneous basal cell carcinoma and squamous cell carcinoma. J Invest Dermatol 2013; 133: 1188-96.

e57. Lansbury L, Bath-Hextall F, Perkins W, Stanton W, Leonardi-Bee J: Interventions for non-metastatic squamous cell carcinoma of the skin: systematic review and pooled analysis of observational studies. BMJ 2013; 347: f6153.

e58. Brodland DG, Zitelli JA: Surgical margins for excision of primary cutaneous squamous cell carcinoma. J Am Acad Dermatol 1992; 27 241-8

e59. Bertino G, Sersa G, De Terlizzi F, et al.: European Research on Electrochemotherapy in Head and Neck Cancer (EURECA) project results of the treatment of skin cancer. Eur J Cancer 2016; 63: 41-52.

e60. Guminski A, Lim AM, Khushalani NI, et al.: Phase 2 study of cemiplimab, a human monoclonal anti-PD-1, in patients (pts) with metastatic cutaneous squamous cell carcinoma (mCSCC; Group 1): 12-month follow-up. J Clin Oncol 2019; 37: 9526.

e61. Migden MR, Khushalani NI, Chang AL, et al.: Primary analysis of phase 2 results of cemiplimab, a human monoclonal anti-PD-1, in patients with locally advanced cutaneous squamous cell carcinoma. J Clin Oncol 2019; 37: 6015.

e62. Maubec E, Boubaya M, Petrow P, et al.: Pembrolizumab as first-line therapy in patients with unresectable cutaneous squamous cell carcinoma (cSCC): Phase 2 results from CARSKIN. J Clin Oncol 2019; 37: 9547 .

e63. Hillen U, Leiter U, Haase $S$, et al.: Advanced cutaneous squamous cell carcinoma: a retrospective analysis of patient profiles and treatment patterns-results of a non-interventional study of the DeCOG. Eur J Cancer 2018: 96: 34-43. 